Portland State University

PDXScholar

Summer 2021

\title{
Understanding the Taboo of Incest in the American South through Analysis of Southern Gothic Literature
}

Grace Young

Portland State University

Follow this and additional works at: https://pdxscholar.library.pdx.edu/honorstheses

Part of the American Literature Commons, American Popular Culture Commons, Appalachian Studies Commons, and the Other Languages, Societies, and Cultures Commons

Let us know how access to this document benefits you.

\section{Recommended Citation}

Young, Grace, "Understanding the Taboo of Incest in the American South through Analysis of Southern Gothic Literature" (2021). University Honors Theses. Paper 1141.

https://doi.org/10.15760/honors.1172

This Thesis is brought to you for free and open access. It has been accepted for inclusion in University Honors Theses by an authorized administrator of PDXScholar. Please contact us if we can make this document more accessible: pdxscholar@pdx.edu. 
Understanding The Taboo of Incest In The American South Through Analysis of Southern Gothic Litrature

by

Grace Young

An undergraduate honors thesis submitted in partial fulfillment of the requirements for the degree of

Bachelor of Arts

in

University Honors

and

English

Thesis Advisor

Hilldy Miller

Portland State University

2021 


\section{Introduction:}

Taboos shift from culture to culture around the world but one that is often shared in being a sure sign of taboo is that of incest. For my paper, I am defining incest as a sexual realtionship between close family blood ties belonging to siblings, cousins, aunts and uncles, parents and children. Relationships between these family members are illegal in the United States. Places like Israel, Argentina, Brazil, India, Ivory Coast, Japan, Latvia, South Korea, Turkey, and Thailand allow incest without legal repercussions if each person is a consenting adult of a certain age. Even though the law is accepting of this practice in these countries, that does not mean social stigma is not attached to it. In the case of Italy, incest is legal but if the incestious relationship were to provoke some sort of public scandal, it would then become illegal (Article 564 Penal Code). For Italy, it is as taboo in the social realm as it is in America but if kept in the shadows, it is allowed. I find Italy's case interesting because once it is noticed in a social way, it is taboo but if kept behind closed doors or a small community, it is allowed in the eyes of the law. America is much like this regarding the social taboo of incest and this may be the cause for such secrecy when discussing incest in a family. Incest is not in news headlines as much as other sex crimes (for example, child molestation in the Catholic church and student teacher realtionships in high schools). It differs from Italy in the way that if there is no scandal, it is still illegal.

For the purpose of this paper, I will be focusing on America and specifically the American South. I am interested in the reputation that the South has had regarding incest in that region. Many references to Southerns being inbred have come from humor, pop culture, fashion and film. I plan to explore the genre of Southern Gothic literature which I plan to analyze themes of incest, taboo, and family secrets. For cases of pop culture, incestous characters are portrayed 
in Hollywood films like Deliverance (1972) which features a young boy who is supposed to be inbred which is played by Billy Redden. Many people to this day are not sure if Billy Redden is actually inbred or not. The film Deliverance characterized the rural south and inbred individuals as unintelligent and with no feeling. In another instance, the popular fashion brand Abercrombie \& Fitch released a t-shirt in 2004 that had a logo of the state of West Virginia with the writing, "It's all relative in West Virginia." (James Dao).

Even though many of these cases in popular culture are harmful stereotypes, in the case of Southern Gothic literature, there is some truth to be gleaned. I want to know why the south has the reputation it does and why the rest of America does not, even though incest is not a geographical thing and can happen in any region of the country. What makes the south the butt of the joke? Through my research, I have found evidence that involves geographical occurrences, race, poverty, and religion. Four of these themes will be explored in depth to bring a better understanding to why the south is considered to be more incestous than other parts of the country. First, geographical instances will be explored ranging from the Appalachian mountains to the flatter lands of Alabama and the people who lived in these regions had isolation from larger populated areas may have led to incestous behavior. Second, I am looking exclusively at poor, white Southerners and excluding the rest of the South which is made up of a variety of different races, cultures, and class dynamics. The reason for this is because due to the very long decades of chattel slavery, black families were not fortunate enough to keep their blood family together because of the slave trade. White families had a much better chance of being with their blood relatives which led to more chances of incest. While on the topic of race, I plan to speak about the harmful Eugenics movement that became popular in the South during the 1930s and 1940s which was a racial ideology of creating a more "desirable race" which meant "white". 
Eugenics was popular among racist and poverty stricken whites during this time and due to misinformation and lack of education. The "selective breeding" that the Eugenics movement spoke about was not directly speaking about incest. Third, I look at white southerners who fall below the poverty line because the stereotype of the "poor, uneducated, inbred person" seems to be more prevalent than speaking about the upper class. Lastly, the religion of Christinaity is a large part of the South's identity and culture. The taboo (and taboo in general) of incest seems to be aplified by being judged by not only the small community but by God. When I do literature analysis, every story I come across speaks of religion being one of the biggest fears for regretting engaging in incestious acts.

Understandably, instances of incest are seldom reported due to social stigma so it is difficult to find first hand accounts of incest relationships but further in this paper, I do explore a video of a first hand account of people who are products of incest. Their point of view is interesting because I have found that they did not feel much shame about their situation but were more nonchalant about the fact instead of shameful. There is background information provided by the creator of the video that the community surrounding the family did not feel ashamed of, which will be further elaborated on. This is where my analysis of Cormac McCarthy's book Outer Dark (1968) is used to discover more about the social taboo of incest in the south and how community judgement comes into play. Outer Dark is the story of a brother and sister who live in Appalachia and bear a child together. Even though the book is fiction, it offers a very real situation of what it was like to be ostracized or "othered" in a small southern community over the taboo of incest. Along with McCarthy, I write about Faulkner and Breece D'J Pancake and their instances of incest in their stories which also have the themes of the "other", taboo, religion, and race which are all Southern Gothic corner stones. Faulkner's Abslom, Abslom is centered around 
family dynamics and cultural stereotypes of the South while Pancake's short story The Mark centers around a brother and sister who have had a previous incestious relationship. Even though the writings I reference are works of fiction, they act as a cultural inside perspective (from southern authors who) into incestual relationships that is hard to come by in real first hand accounts due to the social stigma.

\section{History of Incest in Other Cultures}

Incest has not always been seen as such a taboo in other cultures. In fact, the practice has been observed in many different cultures ranging from the Egyptians, the royal British, the Spaniards, and Austrian nobility. The reasons vary from culture to culture but something that they all have in common is that incest was pracitced in the upper class and it was used to preserve a certain bloodline. Egyptian pharaohs believed they were almost like Gods themselves and were separated from their common man due to their high position. In their position, they were believed to have been able to speak to the Gods which is something a common man could not do. To ensure that the contact between Gods and pharaohs was not broken, the Egyptian royals engaged in incest to make sure the bloodline was "pure." Another reason for Egyptian incest is many Egyptian God creation stories involved siblings marrying one another. Some scholars believe that when Egyptian Gods married their siblings, "they were acting like Gods themselves and were trying to become closer to their divinity" (Bridarolli). Unfortunately for the pharaohs, their incestous behavior led to physical deformities like cleft palate and hydrocephalus. The pharaoh known as Tutankhamun was a child born from a first-degree brother-sister relationship between Akhenaten and Akhenaten's sister. “Tutankhamun had a congenital equinovarus deformity (or 'clubfoot') and some form of gynecomastia" (Bridarolli). Like the 
Egyptian folklore, Japanese creation stories also share tales of incest.The devine brother and sister Izanagi and Izanami married and their copulation produced the Japanese islands (Gary).

Probably the most well known historical family that is involved with incest is the Habsburg Monarchy. In an analysis published by Annals of Human Biology, researchers mainly looked at The Spanish Habsburgs who had photorealistic portraits of them which documented the Habsburg jaw. The Habsburg Jaw is a deformity found in people who have participated in long lines of incest and consists of, "sharlpy jutting jaws, bulbous lower lips and long noses" (Thulin). Obviously, this deformity was named after the family. Em Thompson writes in Journal of Medical Genetics, "The Habsburgs suffered from various other ailments including asthma, gout, dropsy, epilepsy, inner ear infections, and mental stress (Thompson, 839)." The most notable of the Habsburg line to suffer such pronounced deformities was Charles V of Spain who happened to be the Holy Roman Emperor. His deformed jaw made it impossible for his mouth to close fully which interfered with his ability to speak (Thompson, 839). The reason for the Habsburgs inbreeding was much like the rest of royalty that engaged in the act. Not only to keep a "pure" bloodline but also to ensure power stayed within the family. If no other families married into the monarchy, then there was no threat of an outside source trying to take their power, hence why incest was still practiced even though there was physical deformities prevalent over two decades. Power was more important than health.

Incest is a complex social issue, and while it is generally regarded as taboo in most modern countries, many cultures and societies in the past have had different reasons for engaging in the act. Of course, not just royal members of societies were the only people engaging in incest. Many peasants and common folk most likely engaged in these acts too but the royalty and high society were documented much more during history. Something I would like to point out is that 
America has never had a sense of "royalty". There has always been an elite upper class regarding economics in America but no sense of royal family members which never meant there was pressure to keep a bloodline "pure". The pressure to keep wealth in an American (both modern and from the origins of the country) family usually revolves around wealthy families marrying into wealthy families. In regard to incest in the South, the stereotype of incest has been put upon and examinied in lower class white folks more than the southern aristocracy. While there is some truth in this stereotype, the next portion of my paper will examine the reasons why incest was pracited more in lower class white Southern communities rather than the rest of the United States and aristocratic southern society.

\section{Geography and Isolation}

The Appalachian Mountain range starts in Georgia and runs all the way up to Maine. Appalachian culture is strongest in the south-east states of Alabama, Georgia, Tennessee, Kentucky, North and South Carolina, West Virginia, and Virginia. The vast and treacherous mountain range known as the Cumberland Mountains made it extremely difficult for railroads to be built near communities which caused isolation. The main job prospects during the 1800's and early 1900's was coal mining. This job was not heavily sought after due to extreme danger from imploding mines and explosions and more Americans were flocking to cities to work in factories. This caused Appalachian culture to be very resourceful in aspects of food gathering, medical experience, and caused education to be not as important because working in a homestead environment was vital. During the industrialization period of America from the 1790's to 1830 's, most Appalachian communities were left out of these developments except for minor railroads. During the 1930s, the most education children in Appalachia received was learning how to read or being read the Bible in small, one room school houses (Alvic, p. 1551). 
The term "hillbilly" was coined in the popular southern lexicon during the 1930s to describe those who lived in small Appalachian communities.

Outsider migration was slow to these parts of the south due to less job opportunities and transit being sparse. Not much attention was paid to these communities until the 1880's and 1890's when southern writers Mary Noailles Murfee and John Fox Jr ventured into Appalachian communities to examine and report back the learnings for their writing. The majority of both writers stories were fiction but their inspiration was drawn from assuming many things about overcrowded family houses with up to 10 to 12 people living in a home. In John Fox Jr. story titled A Cumberland Vendetta and Other Stories (1896), tells a story of mountain folk who engage in incestuous behavior. John Fox Jr. did not base this off an actual family and all of his assumptions came from his own guessing of how an isolated community could produce so many people in one homestead. During the era of the turn of the 19th century, incest was much more a myth than concrete. Anthropologist Robert Tincher published a study titled "Night Comes to the Chromosomes: Inbreeding and Population in Southern Appalachia (1980)" which dispels many of the assumptions made by Murfee and Fox. Tincher examined over 140 years worth of marriage certification and came to the conclusion that, "inbreeding levels in Appalachia are neither unique nor particularly common to the region based on tracing marriage licenses (Tincher, 34)." I do find Robert Tincher's study helpful in the ways of tracking Appalchian family lines but he underestimates how many individuals in the Appalachian region filed for marriage certificates. With severe poverty in the Appalchian country regions, marriage licenses often cost money and this is something that some folks went without. The communities that Murfee and Fox Jr observed were most likely not documented due to financial reasons or due to births being done at home with no track record of children being born. I can draw from my own 
life as an example. Two of my cousins who were adopted into my family from Townes County, Georgia which is a part of the Appalachian region, were born at home with no birth certificate without any documentation of age or parental lineage during the years of 2000 and 2003 . To this day, they do not know their actual age but can go off of dental records, medical records, and dates that were given to them by Georgia Social Services. While studies have been done on documented lineage, I feel that there should always be an accountancy for undocumented births and family linegage, espically for those in low income areas who did not seek medical assistance with birth and do not file for marriage lisences.

\section{Religion}

In the South, and especially in the Appalachian culture, religion is extremely prevalent, important, and regarded with extreme caution and care. The major religion is Christianty and within the Christian sectors, Baptist, Evangelical, and Penecostal are the most common. Education during the 1930's to the 1950's was not very obtainable or desirable in low income Southern areas like Appalchia. It was not uncommon for people to not be able to read and write but memorization and being able to read certain Bible passages was common. Many folk songs that came from the culture mainly revolve around Christanity and small churches were at the center of social interactions. Majority of town news, commerce, gossip, and normal everyday chatter often took place in various churchyards. With Christainy having such prevalence in a community, the judgement of not just the community is overwhelming but there is an ever present judgment of your life choices that comes from Christ which hangs over Southern Gothic stories like the eyes of Doctor T.J. Eckleburg from The Great Gatsby. In these regions of the country, the Christian Bible is taken extremely seriously when it comes to social taboos, which we still see in modern Southern culture in regards to homosexuality (many people use the Bible 
as their reason to justify their intolerance for homosexuality). As for what the Bible says about incest, there is not much. Prohibited relationships are covered in Leviticus 18:7-18, 20:11-21 and The Old Testament (Wenham). Here, there is a list of fifteen different types of relationships that could happen within a family (including sleeping with a brother or sister-in-law which does not count as incest but is still punishable in the eyes of the Lord). This list of prohibited relationships does not go into great detail but does serve as a simple set of rules for those who follow the Christian faith: if engaging in incetous relationships, that is a sin in the eyes of God. Another religious story that involves incest is the story of Lot. In the book of Genesis, Lot flees the city of Sodom and finds refuge in a cave with his two daughters. Both daughters get Lot drunk and have an incestous relationship with their father (without his consent because he is under the influence of alcohol) because they believe they are the only humans left on Earth to repopulate. In the Bible version, Lot is very unhappy with what his daughter have done to him and he seeks forgiveness from God for the sin that has taken place (Gen 2.5). Later during the Medieval art movement, Lot was painted as enjoying the seduction from his daughters instead of feeling guilt and shame but this is most likely due to the movement itself and the artist's liberties (Mellinkoff, 828).

Much of life in Southern communities from the 1930s to 1950s were centered around Christian life so the Bible was used for making social rules and taboos. That being said, many people interpret the Bible in different ways which means some things are skewed to try and benefit the person and what they have in mind. Some Christians will use the Bible to try and justify their cultural practises of homophobia, racism, and sexism in the Bible as their way to explain their point of view. I think incest is akin to this just in the sense of how things are deemed as taboo and why they are deemed such. I am not saying homosexual relationships and 
incestual relationships are similar but what I am saying is there is a common thread of what constitutes "social norms" and in the South, the Bible is a common factor that people use to defend their argument of what a family should look like and how they should operate in the eyes of the Lord.

In the study of sociology, family structures are of great interest. Family dynamics have been studied in different cultures and how they vary in the roles each family member plays is different for each culture. For example, if you were to look at an African family and a Scandanavian family, each family member would differ in roles that they play and how each member is expected to act in their roles. In American culture, the nuclear family, also known as the elementary family, has been in previous years the most common and upheld style of family. Merriam-Webster dictionary defines nuclear family as, "a family group that consists of only parents and children." Usually, in the context of American culture, this pertains to a mother, father, and children. The power dynamics within the family are very important to American culture, especially in the south during the 1930s to the 1950s. The father is the main source of income, the mother rears children and takes care of the home, and children are raised to obey the parents in the roles they are supposed to play. It is not a stretch to say that American culture still clings to the idea of the nuclear family today. Many politicians run on platforms that tend to want to keep the "American family together and uphold tradition" which always implies the nuclear family. I believe a reason for incest to be such a taboo in America is because it implodes the power dynamic of a family. The troubling thing about incest and the strong power dynamic of the American family is that within the family structure, there is a strong need to keep the acts of incest a secret because of the social shame. In an article written by Mia Fontaine published in The Atlantic titled "America Has an Incest Problem" she states, "One in three-to-four girls, and 
one in five-to-seven boys are sexually abused before they turn 18, an overwhelming incidence of which happens within the family. These statistics were well known among industry professionals, who are often quick to add 'and this is a notoriously underreported crime.'(Fontaine)." The reasons for the underreporting of crimes comes from family dynamics of protection that children have from parents or extended family. Fontaine goes on to write, "Given the prevalence of incest, and that the family is the basic unit upon which society rests, incest tears at the fabrics of society. Consciously and unconsciously, collectively and individually, accepting and dealing with the full depth and scope of incest is not something society is prepared to do," (Fontaine). With family structure and Chrisanity being so important to the Southern society and culture, it makes incest that much more taboo and harder to confront. If judgment from society is too much to bear, there is the added pressure of the Lord.

\section{Race}

In the American South, the anxiety about race is extremely prevalent just as much as religion. American slavery has stained the South which is something the whole country is still reckoning with. After the civil war when slavery was abloshied, many Jim Crow laws were implemented along with strong racist ideology, just continuing the long history of terroizing BIPOC. Organizations like the Ku Klux Klan were formed to terrorize black Americans which resulted in many to take migration to the north. One of the ideologies that gripped the South during the 1930s and 1940s was the Eugenics Movement. Francis Galton in his journal titled "Eugenics: Its Definition, Scope, and Aims" defines Eugenics as "a set of beliefs and practices that aim to improve the genetic quality of the human population specifically excluding people and groups judged to be inferior or promoting those judged to be superior,(Galton)." White 
Southerners who believed in this movement often had intentions to further the population of the white race while sterilizing or hindering the growth of Black southerners through the South. Interracial marriage and relationships were extremely looked down upon and illegal. The ignorant fear of being the minority of the black people of the south was an idea that Eugenics preyed upon.

William Faulkner explores this situation in his story Absalom, Absalom (1936). Faulkner uses the story of the Sutpen family to give criticism to certain aspects that the South have a reputation for and in this case it is slavery, racism, and incest. Being a Southerner himself, he felt proud to be from the South but also was reckoning with the terrible representations of the South that were true. Absalom was Faulkner's way to represent everything that is wrong with the South through a family that is morally corrupt. The story follows a wealthy plantation owner by the name of Thomas Sutpen who was confronted with a complex moral situation. Thomas Sutpen has two children named Henry Sutpen and Julia Sutpen, who are white and born to a white mother, but also has many illegitimate children with the women slaves he owns and implores on his plantation. One holiday, his son Henry brings home a friend from college named Charles Bon who falls for Julia and would like to marry her. Charles Bon is a well liked white man who has a promising future and the townspeople assume they will get married. Thomas Sutpen is the only one who knows two secrets about Charles Bon: Charles Bon is actually Thomas Sutpen's illegitimate son who was born to a woman of color that he was once married to but divorced her after he found out she had black ancestors (meaning Charles Bon is not white due to the "one drop of black blood rule" even though he is white passing). Charles Bon is unaware that Julia is actually his half sister and that Thomas is his father. Thomas Sutpen also has the knowledge that his son, Henry Sutpen, is in love with his sister Julia and would like to marry her. Thomas then 
makes the decision to release the information that Charles Bon is black and forbids Julia from marrying Charles Bon because he does not want his daughter married to a black man and decides that having his two white children marry each other is much better than having black blood mixed in their family. Charles Bon and Julia go ahead with their wedding but Henry Sutpen kills Charles so he can have his marriage to his sister. Julia does not have much say in the matter and even though Thomas Sutpen is not happy with the decision of incest, he feels he has made the right decison.

In simple terms, each option that Thomas Sutpen has regarding his daughter's marriage involves incest. To Thomas, marrying a white person within your family who is white is better than marrying someone who is black or has black blood. This is a sentiment that was shared in both rich and poor Southern folks prior to the Eugenics movement but became increasingly more popular during the movement and as the South kept the same racist mindset even after the Civil War ended. To the modern audience, it seems preposterous to think this, and to a biologist, it's even more mind boggling. Once the slaves were emancipated, many Black Americans now became a large part of the population of the South and this disturbed both classes of white people. The fear of being "replaced" from a land they thought was theirs became concerning and that's how the Eugenics Movement fit in with the south. The most popular criticism of the Eugenics Movement is how the ideals are based in white supremacy and racism because they hold another race more favourable and superior over another race. Another criticism is that it can lead to inbreeding, like we saw in the story of Abslom, Abslom. With many undereducated people in the South during the reconstruction era, they did not grasp the concept that inbreeding can lead to actually "less pure" bloodlines (by their standards) by leading to genetic mutations, disabilities, illnesses, and death. Eugenics Movement not only gained traction in America, but 
was popular in Nazi Germany during the 1940s. Through their ignorance, they believed that by breeding with something close to the family line would create the "desirable race" which in their minds, was Eurocentric features.

\section{Analysis of Incest in Outer Dark}

Outer Dark by Cormac McCarthy was published in 1968 and was the author's second book. The time and setting are not told but many indications from structures, dialogue, and dialect place it in Appalachia during the 1920s. The story revolves around a brother named Culla and his sister named Rinthy who live in a small shack away from people. They have a baby together but Culla feels deep shame so he goes to leave the baby to die in the forest so no one will find out what they have done. Rinthy wants to keep the baby and does not care about the origins of the baby's conception. While Rinthy is asleep, Culla leaves the baby in a swamp but a traveling Vagabond finds the baby and decides to take him without Culla's knowledge. Rinthy is heartbroken and leaves the shack in search of her baby. A few weeks later, Culla sets out to find her because he does not want her telling the secret and because she is the last person he has left alive in his family. After meeting many characters throughout different towns, Rinthy tracks down the Vagabond and pleads to have her baby back. He tells her he no longer has the baby but will tell her where the baby is. The Vagabond soon gets suspicious that the baby was conceived with Rinthy's brother which disgusts him and threatens to kill Rinthy if she does not leave him alone. In the end, Culla finds Rinthy and they live together but Rinthy flees and becomes a vagabond herself. She finds the body of her baby who had been burned up and the Vagabond hanging from a tree. She decides to live in the woods for the rest of her life. 
The themes of this story has heavy religious overtones and deals with incest, family secrets, sin, and infanticide. The opening page starts with a dream that Culla is having and it sets the tone of the whole book:

"This hour the sun would darken and all these souls would be cured of their afflictions before it appeared again. And the dreamer himself was caught up among the supplicants and when they had been blessed and the sun began to blacken he did push forward and hold up his hand and call out. Me, he cried. Can I be cured? The prophet looked down as if surprised to see him there amidst such pariahs. The sun paused. He said: Yes, I think perhaps you will be cured. Then the sun buckled and dark fell like a shout. Now the dreamer grew fearful. Voices were being raised against him. He was caught up in the crowd and the stink of their rags filled his nostrils (McCarthy, 5)."

From the very start, the reader gets the idea that Culla is very ashamed for his sin of incest and is begging to be forgaven by God as well as those who will scorn him. In the dream, God does not get the chance to absolve Culla of his sins and is punished by the crowd. This is foreshadowing for the end of the book because he is never absolved for his sins. In Southern Gothic Literature, secrets are a common theme and most secrets are the kinds that can unravel a whole person's life. To Culla, God's judgement seems to be more powerful than what townspeople think but he is concerned that if the secret is out, there may be harassment and scorn which would cut him off from the community entirely. When Rinthy is about to give birth, she has an exchange with her brother:

"You said you'd fetch her [midwife], " said Rinthy. "I said maybe," Culla replied.

"Fetch her now" "I cain't. She'd tell."

"Who is they to tell?"

"Anybody"

"You could give her a dollar. Couldn't you give her a dollar not to tell and she'd not tell?"

"No." (McCarthy, 10).

Culla is more concerned with the secret than having adequate care for Rinthy. It crosses his mind that she may die in childbirth but then the problem would be resolved. Once the baby is born, 
Culla immediately brings it to the woods to die and upon returning, sees that Rinthy is upset but alive, and producing milk. McCarthy writes, "When he looked at her again and the light falling slant wise across her he could see two dark milkstains like tears in the thin cotton cloth on her chest. He looked away. His hands lay palm upward on his thighs and he sat watching them as if they were somehow unaccountable (McCarthy, 30)". Culla deeply regrets what he has done and now realizes he must pay for the sin. His survival depends on being accepted by the community because if they were to shun him, he would no longer be able to buy food or find work in town. He knows word will travel all across counties so he would have to become homeless or die in the woods.

McCarthy continues to drop hints of God's judgement throughout the book and the consequence of sin being the biggest theme. Not only is Culla bearing the sin of incest but attempted infanticide. There is a balance of innocence and deviousness that is always kept on a fine line within the story. A small family living in isolation in the vast nature countryside living a simple life is innocent enough. William Schafer wrote an article published in Appalachian Journal titled, "Cormac McCarthy: The Hard Wages of Original Sin” which speaks about the concept of Original Sin in the story and underscores the light and dark of the situation. He writes,

"Culla and Rinthy have lived in total familial isolation, a raw state of nature, cut off completely from the rest of humanity. Like Adam and Eve, they have coupled and created a child, while conscious of the sinfulness of their deed. He is highly conscious of $\sin$ but she is driven by the need to find and protect her child (Schafer, 112).”

To underscore the nature of the sin, the Vagabond who finds the child is a man who sells pornographic photos and prophylactics. He is not a good man who is going to give a good home to the baby. The search for the baby leads the pair into the outer darkness of their safe living situation where they find oddity and dark chaos in the likes of murderous men, floods, and 
mean-hearted bosses. Something interesting is that Culla and Rinthy are never fully punished for their sins. Shafer goes on to write,

"Neither Culla nor Rinthy is punished for their sin, but their child is finally found, by now scarred and maimed from its travels, and killed by the murderous men who roam the countryside. The Vagabond is hanged in a tree like a sign of warning, left for birds to pick. The punishment for Culla and Rinthy is not death at the hands of these violent men but eternal, mindless wandering, condemnation to the life of imprisonment in a dark and pathless world (Shafer, 112)."

The story reads like a parable but also gives insight for what a southern community would do if they heard about an incest child. Banishment is at the top of the list. Culla never gets the salvation that he dreamed about in the end and is left in a world that does not recognize him. Shafer sums it up perfectly with, "The innocent suffer and die, the guilty trudge down endless dead-end roads into the middle of nowhere (Shafer,112)."

It seems like the characters of Rinthy and Culla are doomed even before incest takes place. They have no parents and no kin to speak of when people ask where they hail from. They can give no concrete answer and this makes the townspeople uneasy or take pity. Culla has enough cognitive knowledge of sin to feel guilt but Rinthy does not care for the sin. The love of her child overrides everything like the scorn of the townspeople or God. Rinthy knows what has happened is a sin but does not seem to care of the secret getting out even though this would mean banishment from the community. McCarthy sets up that Rinthy was doomed to live a hard existence from the moment she was born. Worse than being punished, she lives in a purgatory state of Outer Darkness.

\section{Analysis of Incest in "The Mark"}

Breece D'J Pancake is an unknown figure to most in the Southern Gothic Literature world. He was exclusively a short story writer that was mostly published in The Atlantic Monthly. Pancake did not live long enough to see his stories be published in a book, which is the 
only one published, titled The Stories of Breece D'J Pancake (1983). Pancake lived a haunting, lonely, and sad life and eventually took his own life in 1979 when he was 26 . The characters of his stories live much like Pancake himself. They take place in run-down mill towns of the Appalchian region and the characters bide their time between dead end jobs, lonely nights out on the town, and family structures that are imploding. The liminal spaces that the characters live in between light and darkness is a theme that is also occurring in Outer Darkness which is a staple in the Southern Gothic genre.

In the short story titled "The Mark", a newly wed woman named Reva is displeased with her marriage and life. She can't stop thinking of her brother, Clinton, who is away from home working on a dangerous job in the National Guard. Her husband Tyler does everything he can to try and make her happy but Reva seems to never be pleased. Reva is pregnant but does not like to talk about the subject even though Tyler is very happy about the baby. Throughout the story, Pancake slowly shows the reader through flashbacks of Reva's memory that the baby she is carrying may be her brother's baby instead of her husbands. The reason for Reva's unhappiness is due to her true love for her brother and wanting to be with him instead of her husband. Pancake never lets the reader know why Clinton left his family and home town but it is assumed that he wanted to leave his sister behind because of his jealousy of Tyler and also alludes that he is never coming back. In the end of the story, Reva has a miscarriage and this devestates her because she believes it was her brother's child. She burns down the boathouse on their property where Reva and Clinton used to play as children and also have sex when they became adults. The ending scene is her crying as the boathouse burns and her husband carries her inside.

The themes of "The Mark" include family secrets, taboo, and the grotesque. All of these make up a quintessential tale of Gothic literature. We get the sense of shame Reva has when she 
sees a photo of a grandfather in her house. Pancake writes, "Coming back through the hallway, Reva locked eyes with the stare of her grandfather but, not knowing his young face, kept her pace to the porch (Pancake, 91).” Just like the judgmental eyes of the Lord that Culla was concerned with in Outer Dark, Reva has the stare of her grandfather that she seems to be detached from. Her family lineage is acknowledged and a part of her life which reinforces the taboo of incest. Her decision to choose to marry Tyler instead of staying with her brother could have been a choice on her part to appease family pressures as well as society.

The grotesque theme of the story enters when Reva and her friend, Carlene, visit a sideshow at the local country fair. The two girls witness two spider monkeys breeding in a small cage. The conversation that follows seems to be a metaphor for incest as well as biblical symbolism. Pancake writes:

"Reva pointed to a chicken-wire cage where two spider monkeys bucked in their breeding. Another lay on a shelf near the roof, stroking itself, awaiting his turn. 'I knowned a woman to mark her baby thataway.'

Reva drew her stare away from the monkeys and leveled off scornfully at Carlene's blue eyes.

'Well,' Carllene continued bitterly, my momma told me all about it. Said the gal was nigh onto seven months, an' her husband couldn't drag her away from them monkeys.' Reva looked at the female monkey awaiting her new mount. 'The baby was born lookin' just like a monkey,' Carlene said, bending herself to talk between Reva and the cage. "Momma swears it's the mark of the beast, but she's real partial to that kind of talk.'

'Where is it now?' Reva asked, as if to seek it out.

'Died, I think.' (Pancake, 97)"

In this passage, we have the biblical sense of "mark of the beast" which is someone who has evil and sin within them. Although Carlene may not know about Reva's incest, you can see Reva drawing parallels of the monkey baby with the child she is carrying. Reva's child is miscarried which I find Pancake is using the monkey story as an allegory for Reva. Reva is not grossed out about the tale, she seems enamored and almost wants to "seek out" the child. This could be her 
way of reckoning with the sin she has done and trying to distance herself from the incestual relationship. I find a connection between Rinthy and Reva in not giving as much thought about the incestual babies in question versus the male counterparts who abandon the child and mother due to shame. Both women have the maternal instinct to care for the child's well-being over the judgement of society and God.

Towards the end of the story, Pancake reveals that Reva might have some regret over the relationship but not out of guilt. He writes, "Reva felt a menstrual slip. She was sorry the rabbit had died for nothing. She felt her belly for the child that had never been, and almost wanted the deed undone, even forgotten (Pancake, 98)." This is the only instance of regret that readers see but it is only after the baby has died. Reva may feel guilt for a human life that was lost due to her actions (babies born of incest are at a higher rate of not being carried to full term). When she is crying in front of the boathouse she has burned down, she admits, "She looked up on the porch to her husband. 'I done an awful thing, T.'(Pancake, 99)” Reva is obviously referring to the fire but the readers know this is a confession of her relationship with her brother. She does feel guilt only after the baby has died because she feels that her connection to her brother is lost. She feels abandoned by him and feels she has nothing left in life after the baby is gone. Like Rinthy, the baby was the main priority.

The grotesque story of beastaility that Pancake writes reminds me of Flannery O'Connor's use of monkeys in her work. In her short story, "A Good Man Is Hard To Find” features a monkey in a Chinaberry tree who is chained up outside of a gas station. In her book Wise Blood, the main protagonist of the story's main source of income is dressing up in an ape costume for movie promotion and a real ape appears a few times in the story. Monkeys are not native to the United States so their existence in the Southern landscape seems somewhat sinister 
and unsettling in the setting of the South. The woman who engaged in beasility in "The Mark" is considered to be a sinner and her child as well. It could just be a religious rumor or a myth but it was used to be a warning sign to Reva. The Southern Gothic genre has a knack for grotesque and I have a theory that this is because of how damaged the landscape and economy was after the Civil War. Things were literally falling apart at the seams and the area was economically depressed. The grotesque fits in perfectly with the landscape that was slowly coming back from war.

\section{Soft White Underbelly and Incest Depicted Now}

Southern Gothic literature is still popular in the 21 st century with writers like Donald Ray Pollock (The Devil All The Time, 2011) and Gillian Flynn (Sharp Objects, 2006). The most popular form of telling southern gothic stories, and many other types of stories, is the visual element of television. What comes to mind is the first season of the HBO series True Detective which almost seems like a visual Cormac McCarthy book. As technology changes, so do the media platforms that consumers seek out for their storytelling needs. YouTube is a platform where people can make content and tell their story free of charge. It has changed how people consume news, information, and how people tell their stories to others across the world. A few years ago, I saw a video on the channel titled "Soft White Underbelly" run and created by photographer Mark Laita. The channel consists of interviews Mark conducts with people who are often overlooked or looked down upon in American society. He gives a voice to people who are homeless folks, struggling with addiction, felons, and gang members (among other things). The interviews are conducted with respect and the main goal is to give an honest look into these individuals' lives and a chance for them to tell their stories. 
One of Mark's most viewed videos is titled "Inbred Family- The Whittakers" and was published on July 4th, 2020. This video (as of the date of this thesis being written) is over 19 million views. In the video, The Whittaker family is interviewed in their home in Odd, West Virginia. The family members consist of brothers Ray, Timmy, Freddie, and their sisters/cousins Barbara and Lorraine. There is also a small child in the video but it is not explained how she is related to the family. Each family member is extremely inbred which is apparent in physical and mental appearance. Each brother does not have the ability to speak and Ray uses language by barking like a dog. They live in severe poverty which is shown by their living situation inside of their home. Mark asks a few questions about family relations but Barbara does not understand the questions. Barbara is the member of the family who is most mentally competent. In the videos comment section, people had mixed reactions of empathy, disgust, and fascination. I was surprised by how many people showed support instead of revulsion for these people.

The thing that interested me about this video is that Mark posts a little background about his visit with the family, which is something he rarely does. He says that when he first visited the family in 2004 to take photographs, he was met with aggression and weapons by the neighbors who lived by the Whittakers. The community was skeptical of what Mark wanted and told him that The Whittakers were being taken care of by the community. Once Mark explained his intentions, he was allowed access to film and photograph. This interaction intrigued me so I reached out to Mark. I wanted to know the relationship between the community and The Whittakers. As we have seen in the stories I have anaylzed, banishment and shame from the small southern community when incest is invovled. In the case of the Whittakers, Mark told me that the family was regarded with warmth and were protected from outsiders that wanted to come and oggle the family like zoo animals. In our correspondence, I asked if the family was 
considered a shame in the community and hidden away. He told me that the community is extremely small and regards the Whittakers as just another family in the community that happens to deal with disabilities. A reason why I think the Whittaker family is accepted is because their incest is so outwardly obvious that you can not hide it. In other instances, like in the stories we have read, the characters are trying their hardest to deal with their own emotions towards the act as well as make sure others don’t know. Mark was not able to give any more information about the community besides that interaction that he had. The interaction lets me know, and Mark agrees, that the community accepts the Whittakers and does not look down upon them.

\section{Conclusion}

Reflecting on my research, I found that incest in the Southern Gothic genre is an important taboo to explore because it is a topic that is shied away from. Incest is a thing that happens in American home every year but never seems to make news headlines. Cases like Jerry Sandusky, Harvey Weinstein, and Jeffrey Epstein populate the modern media. While I think this is incredibly important to expose these individuals, the situation of incest is often never breached in news headlines because of how underreported the crime is. I have explored the intersectionality of race, religion, and sociological structures of family and how that relates to the Southern Gothic. The combination of racism resulting from the unjust Jim Crow laws, extreme religious teachings, and lack of education creates a situation where incest is more likely to happen due to the intensity of each category. First, the racial aspect I focused on was tied in with the ignorance and lack of education. I believe these two things went hand in hand. When Euginics became popular in the South during the 1930s, poor white individuals who were blind with racism and lack of scientific knolwedge led to ideas that incest would healthier than creating children with a person of color. The reason for exploring race and lack of education and 
how it pertains to incest was because I wanted to show that ignorance is a large factor of why incest occured. Ignorance of science and down right misinformation led to some cases or incest and others came from pure blind hate for another race. When speaking about the South, in a wide range of topics, race is never far from being included because of how entrenched it is in the landscape.

For the aspect of religion, I think it is important to remember that many individuals base their life choices and outlook when they are heavily involved in said religion. For my paper, I looked at how religion caused people to be much more judgemental to others as well as judgemental to themselves because of the scorn that can come from God when sin is created. For the sin of incest, it becomes magnified in the Southern setting because of the shame that is dealt with internally and externally in the community. I believe exploring the religious aspect was important because it explains why such shame can be felt by an individual and how the community can be even more judgemental than usual due to religious undertones. Each writer I analyzed had a character that reckoned with themselves, felt guilt and shame, and wondered about their spot in heaven due to their actions of incest.

I believe the Southern Gothic is often the vehicle to explore incest because the grotesque nature of the genre mixed with the liminal spaces that are crossed lends to some of the darkest things being explored. The works of Faulkner, McCarthy, and Pancake were necessary to analyze because although the stories were fiction, they were not far from the truth of what happens in real life southern homes. These fictional stories gave me access to see the thoughts and inner turmoil of the character who has committed incest and I was able to explore their reasons. The reasons these characters engaged in incest all stemmed from lack of education and religious shame (McCarthy and Pancake) and racism and misinformation (Faulkner). By studying these author's 
stories, I was able to see the South through the eyes of Southerns in a harshly honest way. There was no glorification of the South's triumphs (which they do have) but only focusing on the dark underbelly.

I want to go back and touch on the jokes and reputation that the South has about incest. I touched on this during the introduction but I did not go in full depth of why I believe the South carries this burden of being considered "inbred and stupid". As a child growing up in Southern California, very much removed from the South and its cultural, I often heard jokes that involved Southern people as being dumb and having sex with their own family members. I will not repeat these jokes because they are much too crass for a college educational paper but also I believe these jokes perpetuate a stereotype that is harmful and I don't wish to joke about a serious topic that can cause pain and shame in someone's life. I believe these jokes are used to belittle people of the South. These jokes are made out of ignorance because obviously, not every single person in the South is inbred or unintelligent. Incest can happen in every state and family across the country but the South is the region that has been given the reputation for the act due to their lower education rates and, in the eyes of other ignorant people from the US, their lack of intelligence. It is easy to make jokes about uncomfortable topics instead of actually talking about the situation. I believe incest is such an uncomfortable topic that is barely breaching the surface. I want to drive home the fact that incest truly rips apart the seams of a society and that is why it is so difficult to talk about. As the country becomes more divided politically in modern day, I see more people wanting to seem like they are "better" than others and will use harmful stereotypes to do this.

While incest is not only preformed in the lower class white community of the south, my hope is that this paper has brought to light why this is often a stereotype that is linked to this 
community. To build on this thesis in the future, I would like to explore the lack of education and those who fall below the poverty line versus those with wealth and how this relates to incest. I believe America is in a crisis with misinformation and critical thinking. Misinformation about politics, virus information, and science. We see this on the news with people who read a false article that is written to prey on their fears which leads them to do things like storm the Capitol building and endangering lives. The reason I have singled out education as a future research question is because I believe critical thinking needs to be restored. Looking at facts and being able to discern what is real and what is not seems to be a problem in America right now. Something that I would like to see change in the future is how America talks about incest and how we approach the topic. Incest happens often in America and is one of the most under reported crimes because of the power dynamics that play out between family members. People are afraid to tell on their family members and they are afraid to be seen as a sexual deviant. I want the shame and stigma to be lowered around the topic. I believe that some people see that they have no choice in hiding the secret which can cause further secrecy and makes repeating the act more likely. They may feel that what they have done is so shameful that it can never come to light. I don't believe that. If individuals felt less shame about talking about their involvement in incest, it can be easier to persecute those who wrongfully assulted a family member. I don't believe in removing the stigma of incest all together because as we have seen in examples of my paper, it is an unsafe practice if a baby were to be conceived and it also ruins family relationships and roles within a society. What I would like to see is people who are incest survivours be treated less like a joke and with more understanding because this is a problem that will continue to grow if kept in secret. In my last statement, dark and taboo secrets from the underbelly of a place (in this instance, the South) often seem to always bubble to the top. It is important that we, as 
Americans, try our hardest to understand those who have engaged in incest consesually and not meet them with scorn but understand why such an act took place and start to face the problem of incest in America. 


\section{Works Cited}

[1] Navari, Barbara. “Dei Delitti Contro La Famiglia”. Codice penale, Libro II, Titolo XI.

[2] Dao, James. “T-Shirt Slight Has West Virginia In Arms.” The New York Times. 23 Mar. 2004.

[3] Bridarolli, Alexandra. "Consanguinity and Incest in Ancient Egypt.” UCL. 18 Aug. 2018.

[4] Garry, Jane. "Archetypes and Motifs in Folklore and Literature: A Handbook." Routledge. 5 Jul. 2017.

[5] Thunlin, Lila. “The Distinctive 'Habsburg Jaw' Was Likely the Result of the Royal Family’s Inbreeding." The Smithsonian Magazine. 4 Dec. 2019.

[6] Thompson, Em. “Another Family With The 'Habsburg Jaw'.” Journal of Medical Genetics. 1 Dec. 1988.

[7] Alyic, Philis. "Settlement, Mission, and Sponsored Schools." Encyclopedia of Appalachia. Knoxville: University of Tennessee Press, 2006. p. 1551.

[8] Mellinkoff, Ruth. “Titian's Pastoral Scene: A Unique Rendition of Lot and His Daughters." Renaissance Quarterly. Cambridge University Press. 1998 p. 51.

[10] Galton, Francis. "Eugenics: It's Definition, Scope, and Aims.” The American Journal of Sociology. 1904 p. 82.

[11] Galton, David. "Eugenics: The Future of Human Life in the 21st Century." London Abacus. 2002 p. 48.

[12] Faulkner, William. Absalom, Absalom! New York: Vintage Books, 1972. Print.

[13] McCarthy, Cormac. Outer Dark. New York: Random House, 1968. Print.

[14] Schafer, William J. “Cormac McCarthy: The Hard Wages of Original Sin.” Appalachian Journal. 1977 p. 112. 
[15] Pancake, Breece D.J. The Stories of Breece D’j Pancake. Boston: Little, Brown. 1983. Print.

[16] BlackBurn, Christopher. “The American Pastoral Tradition and The Stories of Breece D'J

Pancake." Georgia Southern University Press. 2017.

[17] Laita, Mark. "Inbred Family - The Whittakers." YouTube, uploaded by Soft White Underbelly, 4 Jul. 2020. https://www.youtube.com/watch?v=nkGiFpJC9LM 